\title{
Effect of micronutrient on quality seed production of soybean
}

\author{
PRITI A. SONKAMBLE*, ARUNA S. KATOLE AND MADHURI M. SADAFALE ${ }^{1}$ \\ Seed Technology Research Unit, Dr. Panjabrao Deshmukh Krishi Vidyapeeth, AKOLA(M.S.) INDIA \\ (Email : sonkamble.priti74@gmail.com)
}

\begin{abstract}
A high quality seed that provides adequate plant stand is the basis for profitable production of soybean crop. Soybean is an energy rich crop and hence the requirement of macro and micro nutrients is high for soybean. The use of micronutrients in soybean is one of the ways to boost up the productivity and to improve the seed quality parameters. Therefore, the field experiment was carried out at Seed Technology Research Unit, Dr. Panjabrao Deshmukh Krishi Vidyapeeth, Akola to study the effect of micronutrient on quality seed production of soybean var. JS-335 during Kharif 2010 and 2011. The experiment consisted of 9 treatment combinations of soil application and foliar spray of $\mathrm{ZnSO}_{4}$ as the experimental field was deficit in Zn. Among all the treatments, significantly highest number of pods per plant (39.50), 100seed wt. (11g.), seed yield (24.60q/ha), highest vigour index (39.48) and seed recovery (91\%) were obtained from the plot treated with $\mathrm{ZnSO}_{4} @ 30 \mathrm{~kg}$ /ha soil application and $\mathrm{ZnSO}_{4} @ 0.5$ per cent foliar spray. Hence, soil application of $\mathrm{ZnSO}_{4} @ 30 \mathrm{~kg} / \mathrm{ha}$ along with foliar spray of $\mathrm{ZnSO} \mathrm{O}_{4} @$ 0.5 per cent found most effective for seed yield and yield contributing characters as well as seed quality parameters.
\end{abstract}

Key Words : Quality, Seed production, Micronutrient, Soybean

View Point Article : Sonkamble, Priti A., Katole, Aruna S. and Sadafale, Madhuri M. (2015). Effect of micronutrient on quality seed production of soybean. Internat. J. agric. Sci., 11 (1): 172-174.

Article History : Received : 24.04.2014; Revised : 05.12.2014; Accepted : 19.12.2014

\footnotetext{
* Author for correspondence

${ }^{1}$ Directorate of Research, Dr. Panjabrao Deshmukh Krishi Vidyapeeth, AKOLA (M.S.) INDIA
} 